
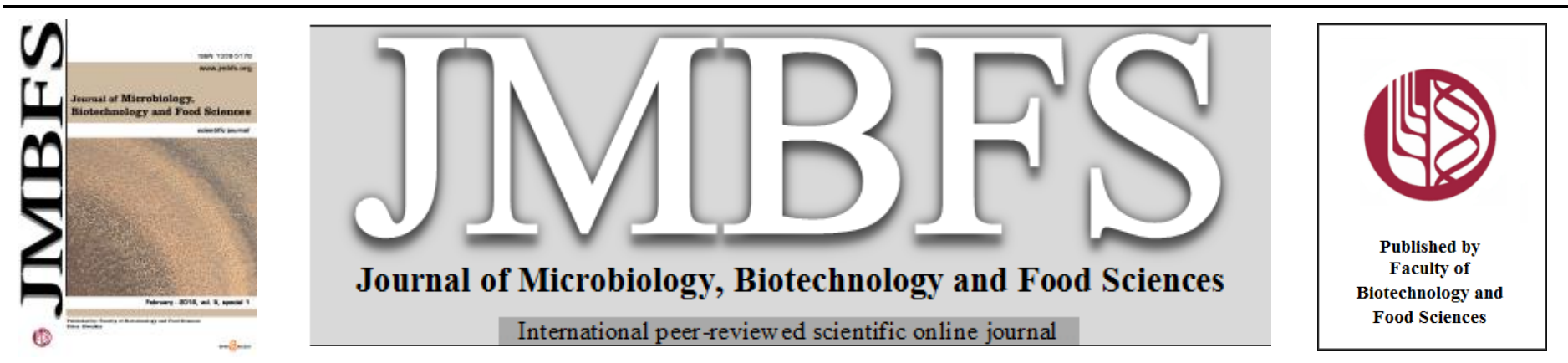

\title{
UTILIZATION OD DIFFERENT MARKERS FOR HEDERA HELIX, L. GERMPLASM EVALUATION
}

\author{
Jana Žiarovská*l, Danka Bošel'ová ${ }^{1}$, Lucia Zeleňáková ${ }^{2}$, Milan Bežo ${ }^{1}$ \\ Address(es): Doc. Ing. PaedDr. Jana Žiarovská, PhD., \\ ${ }^{1}$ SUA in Nitra, Faculty of Agrobiodiversity and Food Resources, Department of Genetics and Plant Breeding, Tr. A. Hlinku 2, 949 76, Nitra, Slovak Republic. \\ ${ }^{2}$ SUA in Nitra, Faculty of Biotechnology and Food Sciences, Department of Food Hygiene and Safety, Tr. A. Hlinku 2, 949 76, Nitra, Slovak Republic.
}

*Corresponding author: jana.ziarovska@uniag.sk

doi: 10.15414/jmbfs.2016.5.special1.23-26

\section{ARTICLE INFO}

Received 2. 12. 2015

Revised 22. 1.2016

Accepted 27. 1.2016

Published 8. 2. 2016

Regular article

OPEN ${ }_{\text {ACCESS }}$

\begin{abstract}
Hedera helix is a plant that is valued for its medicinal properties and on the other hand criticized for its invading potential. Beside its medicinal use, a wide utilization as decorative plant is typical for this specie. Up-to date only a few molecular data are available for Hedera helix genome, thus the aim of the study was to evaluate the utilization of different DNA markers for the its further population studies purposes. In total, eight different DNA marker techniques were used for the PCR analysis - iPBS, BARE1 IRAP, Cassandra IRAP, Tst1 IRAP, HACRE 1 IRAP, RAPD, ISSR and miRNA. In total, 38 different iPBS primers were tested with the best results for primers 2152, 2270, 2079, 1899 and 2033. In the case of RAPD primers, all of them worked in the PCR excellent. For ISSR, only a 42 $\%$ of the used primers provided results that vere evaluated as very good or excellent ISSR profile. The most successful results were obtained by microsatelite repetitions (GA)8T, (CTG)3GC and (TG)10. A novel type of DNA markers - miRNA provided results that are promising for Hedera helix, L. population studies for their further utilization.
\end{abstract}

\section{INTRODUCTION}

Hedera spp. (Araliaceae) is a complex of invasive plant pests that are separated into several distinct taxa. It was introduces mainly as an ornamental plant and upto-date, several similar forms are sold under the general common name of English ivy (Reichard, 2000). Nowadays it is cultivated about 500 different cultures of ivy. Normaly, ivy is popular as decorative plant and has many available cultivars including non-climbing kinds used to cover the soil and compact forms in plots. Thanks to the evergreen and shade-loving qualities, ivy is ideal for conservatories and can create attractive packaging for garden structure.

Hedera helix, L. possess more variants in its morphology and habitat characteristics, it can be found as perennial, herbaceous vine, climber, a herb, a woody subshrub, or very rarely a tree. The stems that are woody, grow in a variable manner as vertically up tree trunks, cliffs or walls, or grow horizontally on the woodland floor (Grime $\boldsymbol{e t}$ al., 1988). In Europe, ivy is distributed from north Africa and the Mediterranean to Norway and eastwards to Latvia and Ukraine, Armenia, Georgia and Iran (Ellenberg, 1988). Laroque (1998) has reported $\mathrm{i}$ tas to be absent in northern and eastern Russia, eastern Poland, the Faroes, Finland, Iceland and Svalbard. The ssp. Hibernica is most common along the Atlantic coast of Europe from Ireland to south-west Spain, while ssp. helix occupies central and eastern Europe as far as the Ukraine (Grivet and Petit 2002). Hedera helix, L. is a groundcover that have been used in urban areas for its pros such as appearance, shade-tolerance and easy propagation. Is was reported previously to be usable for the purpose of erosion control and slope stabilization (Parker, 1996). Mainly for its extensive utilization in Urban areas landscape formation, now it is regarded as the invador (Reichard, 2000).

From the molecular markers point of view, Hedera, spp. is one of the species where only a limited information exist. English ivy, is designed as an example of a genomic plasticity which occurs during typical developmental changes from juvenile to adult phase (Obermayer, 2000). Hedera helix ssp. helix $2 n=48$; ssp. hibernica $2 n=96$ (Vargas et al. 1999). Diploid cell DNA content of juvenile leaves is $3.6 \mathrm{pg}$, and of adult phase leaves $6.2 \mathrm{pg}$ (Schäffner and Nagl, 1979).
The chromosome number is $2 n=48$ for Hedera helix ssp. Helix and $2 n=96$ for ssp. Hibernica (Vargas et al., 1999). Midori et al. (2006) identified in their study Hedera species and cultivars most responsible for the invasion of forests in the Pacific Northwest. They have used the RAPD markers as to be universal through the plant kingdom and compared in total 58 selected populations in British Columbia, Oregon, and Washington. The comparison against nine Hedera taxa resulted in genetic and morphological identification wehere eighty-five percent of the accessions were attributed to Hedera hibernica and fifteen percent to the Hedera helix $\mathrm{L}$.

The aim of the performed analysis reported here is the first insight to the utilization of different DNA markers for the Hedera helix, L. population studies purposes.

\section{MATERIAL AND METHODS}

\section{Plant Material}

Juvenile healthy leaves of Hedera helix, L. were collected in situ during the spring 2015 in the area of Zobor, Nitra. Immediatelly after the collection they were treated with etanol for the purpose of the surface desinfection. When transporting them to the laboratory, they were stored under the $-20^{\circ} \mathrm{C}$ until the further processing. Genomic DNA extraction was performed by GeneJET Plant Genomic DNA kit (ThermoScientific) according the manufacturer instructions. Quantity and quality of extracted DNA was checked by NanoPhotometer P-Class (Implen).

\section{DNA marker terchniques and PCR protocols}

In total, eight different DNA marker techniques were used for the PCR analysis. After the optimization procedure individual techniques follow the final thermal profiles as summarized in table 1 . 
Table 1 Marker techniques and their PCR profiles used in the study.

\begin{tabular}{|c|c|c|c|c|}
\hline Marker technique & $\begin{array}{l}\text { No. of tested } \\
\text { primers }\end{array}$ & Thermal profile of PCR & Reference & Note for technique \\
\hline iPBS & 38 & $\begin{array}{l}95^{\circ} \mathrm{C}-3 \mathrm{~min} ; 35 \text { cycles of: } 95^{\circ} \mathrm{C} 30 \mathrm{~s} \\
55^{\circ} \mathrm{C} 40 \mathrm{~s} ; 72^{\circ} \mathrm{C} 120 \mathrm{~s} ; \text { final } 72^{\circ} \mathrm{C} 5 \mathrm{~min}\end{array}$ & $*$ & universal/specific \\
\hline BARE1 IRAP & 4 & $\begin{array}{l}95^{\circ} \mathrm{C}-3 \mathrm{~min} ; 35 \text { cycles of: } 95^{\circ} \mathrm{C} 45 \mathrm{~s} \\
58^{\circ} \mathrm{C} 60 \mathrm{~s} ; 72^{\circ} \mathrm{C} 120 \mathrm{~s} ; \text { final } 72^{\circ} \mathrm{C} 10 \mathrm{~min}\end{array}$ & $*$ & $\begin{array}{l}\text { specific for BARE } 1 \\
\text { retrotransposon }\end{array}$ \\
\hline Cassandra IRAP & 3 & $\begin{array}{l}95^{\circ} \mathrm{C}-3 \mathrm{~min} ; 35 \text { cycles of: } 95^{\circ} \mathrm{C} 30 \mathrm{~s} \\
55^{\circ} \mathrm{C} 40 \mathrm{~s} ; 72^{\circ} \mathrm{C} 120 \mathrm{~s} ; \text { final } 72^{\circ} \mathrm{C} 5 \mathrm{~min}\end{array}$ & $*$ & $\begin{array}{l}\text { specific for Cassandra } \\
\text { retrotransposon }\end{array}$ \\
\hline Tst1 IRAP & 6 & $\begin{array}{l}94^{\circ} \mathrm{C}-2 \mathrm{~min} ; 35 \text { cycles of: } 94^{\circ} \mathrm{C} 60 \mathrm{~s} ; 55 \\
{ }^{\circ} \mathrm{C} 60 \mathrm{~s} ; 72^{\circ} \mathrm{C} 180 \mathrm{~s} ; \text { final } 72^{\circ} \mathrm{C} 10 \mathrm{~min}\end{array}$ & Bežo et al. (2007) & $\begin{array}{l}\text { specific for Tst } 1 \\
\text { retrotransposon }\end{array}$ \\
\hline HACRE 1 IRAP & 2 & $\begin{array}{l}95^{\circ} \mathrm{C}-3 \mathrm{~min} ; 35 \text { cycles of: } 95^{\circ} \mathrm{C} 30 \mathrm{~s} \\
62^{\circ} \mathrm{C} 40 \mathrm{~s} ; 72^{\circ} \mathrm{C} 120 \mathrm{~s} \text {; final } 72^{\circ} \mathrm{C} 10 \mathrm{~min}\end{array}$ & $\begin{array}{l}\text { Žiarovská and } \\
\text { Bežo (2013) }\end{array}$ & $\begin{array}{l}\text { specific for HACRE } 1 \\
\text { retrotransposon }\end{array}$ \\
\hline RAPD & 6 & $\begin{array}{l}94^{\circ} \mathrm{C}-5 \mathrm{~min} ; 42 \text { cycles of: } 94^{\circ} \mathrm{C} 60 \mathrm{~s} \\
38^{\circ} \mathrm{C} 60 \mathrm{~s} ; 72^{\circ} \mathrm{C} 60 \mathrm{~s} \text {; final } 72^{\circ} \mathrm{C} 5 \mathrm{~min}\end{array}$ & $\begin{array}{l}\text { Vivodík et al. } \\
\text { (2014) }\end{array}$ & universal \\
\hline ISSR & 24 & $\begin{array}{l}95^{\circ} \mathrm{C}-3 \mathrm{~min} ; 32 \text { cycles of: } 95^{\circ} \mathrm{C} 15 \mathrm{~s} ; \\
47^{\circ} \mathrm{C} 40 \mathrm{~s} ; 72^{\circ} \mathrm{C} 120 \mathrm{~s} ; \text { final } 72^{\circ} \mathrm{C} 7 \mathrm{~min} \\
94^{\circ} \mathrm{C} \text { for } 5 \mathrm{~min} \cdot 5 \mathrm{cycles} \text { of } 94^{\circ} \mathrm{C} 30 \mathrm{~s}\end{array}$ & $\begin{array}{l}\text { Batovská et al. } \\
\text { (2010) }\end{array}$ & universal \\
\hline miRNA & 7 & $\begin{array}{l}64^{\circ} \mathrm{C} 45 \mathrm{~s} \text { (temp. decreasing by } 1^{\circ} \mathrm{C} / \text { cycle), } \\
72^{\circ} \mathrm{C} 60 \mathrm{~s} ; 30 \text { cycles } 94^{\circ} \mathrm{C} 30 \mathrm{~s}, 60^{\circ} \mathrm{C} 45 \mathrm{~s}, \\
72^{\circ} \mathrm{C} 60 \mathrm{~s} \text {; final a } 72^{\circ} \mathrm{C} 10 \mathrm{~min} .\end{array}$ & $\begin{array}{l}\text { Hlavačková and } \\
\text { Ražná (2015) }\end{array}$ & $\begin{array}{l}\text { universal/species } \\
\text { specific }\end{array}$ \\
\hline
\end{tabular}

All the amplified products were surveyed for polymorphism using $2 \%$ agarose gel electrophoresis.

\section{RESULTS AND DISCUSSION}

iPBS technique is used for both - isolation of long terminal repeats retrotransposons as well as an efficient and a general marker system. Kalendar et al. (2010) has reported it as suitable for the universal use for both retroviruses and LTR retrotransposons. The method is applicable to any organism with retrotransposons containing primer binding sites that are complementar to the tRNA.

Ones the specific iPBS primers are selected from the universal set for the particular organism, the methoid becames an effective and reproducible one. This is its main pros when comparing it to the unspecific length polymorphism techniques sucha s RAPD or ISSR.

Here, 38 different iPBS primers were tested for the Hedera helix, L. in total. Twelve of them provided no amplification pattern in the ivy genome (figure 1). The best results were obtained for primers 2152, 2270, 2079, 1899 and 2033.

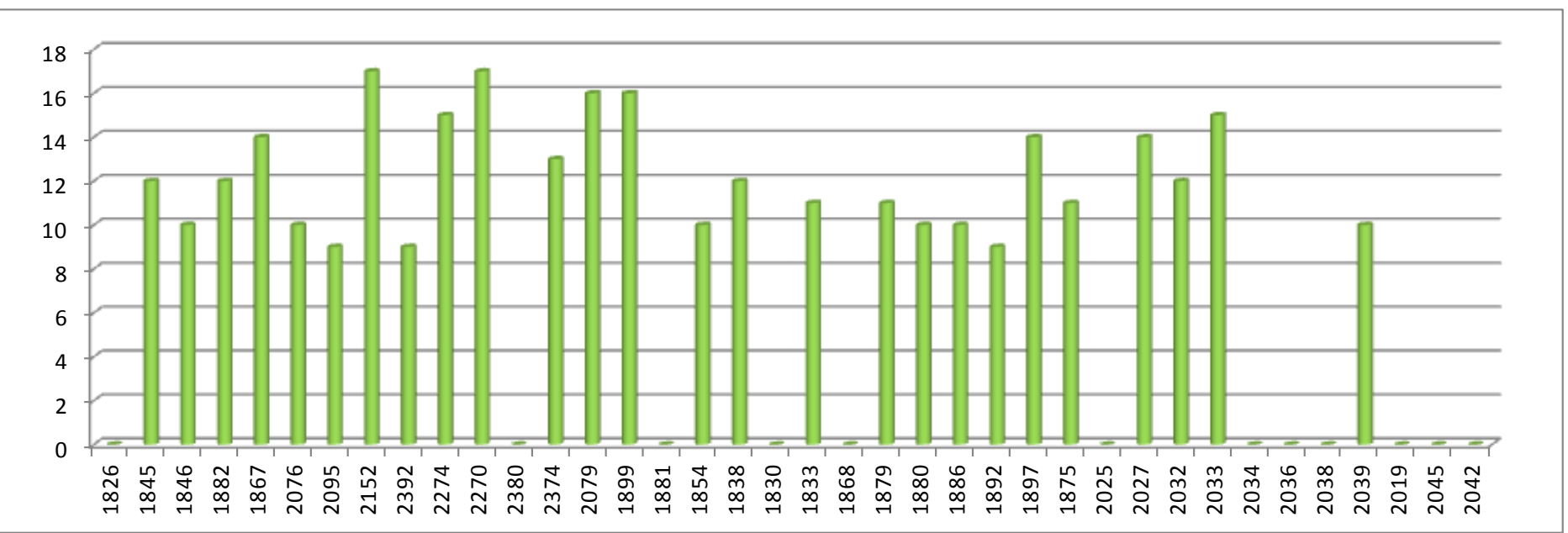

Figure 1 Variability in number of iPBS loci amplification of used primers for the analysed accession of Hedera helix, L. Names (number codes) of iPBS primers are as in the Kalendar et al. (2010)

The method of iPBS was succesfully used for analysis in many different plant species such Linum ussitatisimum (Smýkal et al., 2011), Saussurea esthonica (Gailīte et al., 2011), Liparis loeselii (Belogrudova et al., 2012) or Prunus armeniaca (Baránek et al., 2012) where was prooved as reliable DNA marker system. Along with the iPBS, another retrotransposon based DNA markers such as IRAP, REMAP, RBIP or SSAP are stil used widely for the analysis of genetic relationships (Trebichalský et al., 2013; Balážová et al., 2014; Guo et al., 2014).

Andeden et al. 2012 analyzed the genetic diversity within the species of wild growing chickpeas using iPBS retrotransposons and ISSR markers. In total, 136 eventual bands using 10 ISSR primers among 71 entries belonging to class 6 were detected, out of which 135 were polymorphic $(99,3 \%)$, an average was 13,5 polymorphic fragment per primer, whereas iPBS detected 130 bands of $100 \%$ polymorphism on average 13,0 bands per primer. The average of polymorphic information content value was 0,91 for the both of markers system. The clustering of additions and species within the group was almost the same in preparing iPBS and ISSR planar graph NeghorNet (Nnet).

Further, a set of miRNA markers were tested, using the primers and procedure as reported by Hlavačková and Ražná (2015) with a successful amplification pattern for ivy in the case of the most primer combinations, that were used. The most amplified fragments were achieved for the primer combination mirR $-156 \mathrm{~F}$ and $414 \mathrm{~F}-414 \mathrm{R}$. microRNA length polymorphism marker system was developed by Fu et $\boldsymbol{a l}$. (2013) and is reported as a technique that possess high reproducibility, sufficient polymorphism and high efficiency of production.
MicroRNA are endogenous non-coding RNAs of the genomes of many organisms. The high conservation of miRNA sequences provides an opportunity for developing specific type of a molecular marker.

Although RAPD is a little overcomed today for the polymorphism analysis of genomic well known plant species it still provides a suitable starting point for those of plant, where limited or none genomic data exist (Milella et al., 2005; Vivodík et al., 2015). The basic difficulty about RAPD is the reproducibility that make it not suitable for the transfer among the laboratories (Kumar et al., 2009). It is still used for the purposes of rapid sample authentication, but it is not always possible to replicate the fingerprint because even slight instrumentationdependent variations of PCR can result in variant fingerprints even when the samples of the same genomic DNA are used (Sucher, Carles, 2008).

Here, only a five RAPD primers were tested, as the RAPD polymorphism was evaluated by Midori $\boldsymbol{e t}$ al. (2006) in the only DNA marker based study that is actual for Hedera helix, L.. Among the used primers (RAPD1 - 5'gatacgttgtc 3'; RAPD2 - 5'cagaagcgga 3'; RAPD3 - 5'aggcccgatg 3'; RAPD4 - 5'cctaaccgtgg 3'; RAPD5 - 5'ctggcgtgtc 3'; RAPD6 - 5'acaccgatgg 3'), all of them provided clear and reproducible banding pattern (figure 2 ) 


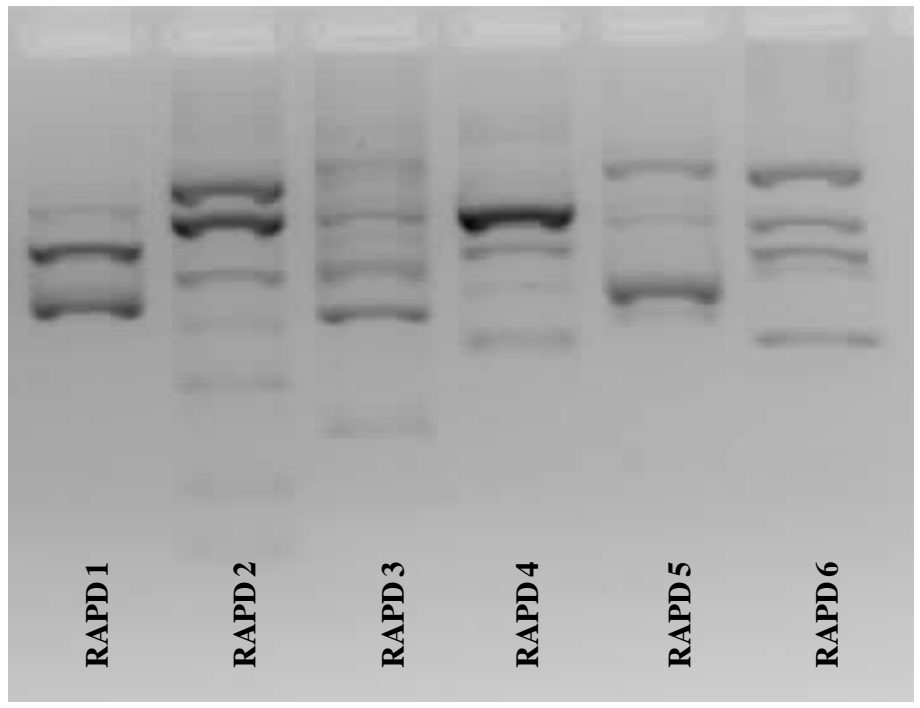

A different results was obtained in the case of used ISSR markers. Out of the 24 primers used for the testing analysis, 10 of them provided reproducible and clear banding pattern. Eight primers provided no banding pattern and vere evaluated as nonsuitable for further analysis (table 2). The size of the amplified fragments ranged from $3200 \mathrm{bp}$ up to the $2 \mathrm{~kb}$. A range from 5 to the 19 fragments were amplified by the positive tested primers for the analysed Hedera helix, L accession. The highest number of bands was obtained by $(\mathrm{CTG})_{3} \mathrm{GC}$ microsatellite repeat and the least number by $(\mathrm{CT})_{8}$.

Figure 2 Banding pattern of the RAPD primers used in the study

Table 2 Banding patterns profiles for tested ISSR primers.

\begin{tabular}{lccc}
\hline Microsatellite repeat & $\begin{array}{c}\text { Amplification pattern in } \\
\text { Hedera helix., } \mathbf{L}\end{array}$ & Microsatellite repeat & $\begin{array}{c}\text { Amplification pattern in } \\
\text { Hedera helix., } \mathbf{L}\end{array}$ \\
\hline$(\mathrm{GA})_{8} \mathrm{~T}$ & Excellent & $(\mathrm{ATG})_{7}$ & Very good \\
$(\mathrm{CA})_{8} \mathrm{G}$ & Very good & $(\mathrm{GA})_{7} \mathrm{G}$ & Very good \\
$(\mathrm{AG})_{10} \mathrm{G}$ & Poor & $\mathrm{CAG}(\mathrm{AC})_{4} \mathrm{AGT}$ & None \\
$(\mathrm{AC})_{10} \mathrm{C}$ & Poor & $(\mathrm{AT})_{8}$ & Very good \\
$(\mathrm{CTC})_{6} \mathrm{~T}$ & Very good & $(\mathrm{GCT})_{7}$ & Poor \\
$(\mathrm{CAC})_{6} \mathrm{C}$ & None & $(\mathrm{TG})_{10}$ & Excellent \\
$(\mathrm{GATA})_{2}(\mathrm{GACA})_{2}$ & Very good & $(\mathrm{GC})_{13}$ & None \\
$(\mathrm{CTG})_{3} \mathrm{GC}$ & Excellent & $(\mathrm{GCA})_{5}(\mathrm{CCA})_{5}$ & None \\
$(\mathrm{CA})_{6} \mathrm{GG}$ & None & $(\mathrm{TTT}) \mathrm{A}_{5}$ & None \\
$(\mathrm{AT})_{8} \mathrm{~T}$ & None & $\mathrm{AG}(\mathrm{TA})_{8}$ & None \\
$(\mathrm{CT})_{8}$ & None & $(\mathrm{AG})_{13}$ & Very good \\
$\mathrm{AGT}(\mathrm{TG})_{6}$ & Poor & $\mathrm{GT}(\mathrm{CA})_{4}$ & None \\
\hline
\end{tabular}

Zhuravlev et al. 2003 investigated genetic relationship within the species of Araliaceae of Far East. By preliminary sreening of 120 commercial primers, 84 primers effective in PCR reaction were selected. Some of them were used in RAPD analysis of 11 species. By comparing of RAPD pattern obtained, variability of 595 loci was estimated.

Morales et al. 2011 used RAPD and ISSR methods in accessing genetic similarity of strawberries. DNA was obtained from 11 cultivars grown unde controlled conditions using 40 RAPD and 16 ISSR markers. DNA fragments isolated in agarose gel were used for RAPD method and in polyakrylamid gel for ISSR method. Matrix of genetic similarity was estimated with Jaccard coeficien of similarity. The dendrogram generated by RAPD markers distributed cultivars into three groups, while ISSR markers generated two groups. From 40 RAPD markers only 11 were polymorphic, the others showed either no effect or only a low amplification quality. By the ISSR markers, 6 from 16 evaluated primers showed good amplification quality. There was no direct relationship detected when both types of markers were compared. The grouping designed by ISSR markers was more in line with the origin and genealogy of cultivars than RAPD markers suggested, which can be considered the most effective method for studying the genetic diversity of strawberries.

Kebour et al. 2012 used ISSR markers in the study of genetic polymorphism in the pistachio, Pistacia vera. During ISSR skreening based on GA (guaninadenin), CA a GAA, good amplifications products were obtained. A total of 111 band, 60 bands were polymorphic $(54,04 \%)$, amplified with 6 primers, average 7 bands per primer. Total number of amplified products were in the range from 5 to 10 and the number of polymorphic fragments in the range of 4 to 7 . The range of genetic similarities reached the level of 0,84 to 1 . The ISSR analysis showed a sufficient polymorphism of a large-scale DNA fingerprinting.

For IRAP analysis test, four different retrotransposons were selected, based on their abundance in plant genomes. All of them, Bare1 retrotransposon, Tst1 retrotransposon, Hacre1 retrotransposon and Cassandra retrotransposon were previously reported as efficient DNA markers for different plant species (Kalendar et al., 2000; Kalendar et al., 2008; Buti et al., 2009). All of them were confirmed as presented in the genome of Hedera helix, L. by performed analysis. In the cases of BARE1, Tst1 and HACRE 1 retrotransposons, the IRAP profile was with low number of amplified bands ranged from 4 up to the 7 bands with the only exception of Barley P04 primer that provided 11 scorable fragments. A much more bands were obtained for Cassandra retrotransposon primers, that were used in the study. They ranged from 17 up to the 24 fragments what is in concordance with the findings, that Cassandra is present up to date in all plants that were analysed for Cassandra IRAP polymorphism (Kalendar $\boldsymbol{e t}$ al., 2008).

\section{CONCLUSION}

For the purposes of molecular analysis of Hedera helix, L., different DNA marker techniques were evaluated in this study. Based on the type of the used technique, different results were obtained in their ability to amplified length polymorphism amplicons by PCR. The most stable techniques that have the potential for the purpose of Hedera helix, L. population studies were iPBS and IRAP technique for Cassandra retrotransposon. A novel type of DNA markers miRNA markers were proved as suitable for the molecular studies of Hedera helix, $\mathrm{L}$.

Acknowledgments: This work has been supported by the European Community under project no 26220220180: Building Research Centre "AgroBioTech".

\section{REFERENCES}

Andeden, E.E., Baloch, F.S., Derya, M., Kilian, B. \& Özkan, H. (2012). iPBS retrotransposons based genetic diversity and realationships among wild annual Cicer species. J Plant Biochem Biotech. 22, 453-466. http://dx.doi.org/10.1007/s135620120175

Balážová, Ž., Trebichalský, A., Gálová, Z., Kalendar, R., Schulman, A., Stratula, O. \& Chňapek, M. (2014). Genetic diversity of triticale cultivars based on microsatellite and retrotransposon-based markers. Journal of Microbiology, Biotechnology and Food Sciences, 3, 58-60.

Baránek, M., Meszáros, M., Sochorová, J., Čechová, J. \& Raddová, J. (2012) Utility of retrotransposon-derived marker systems for differentiation of presumed clones of the apricot cultivar Velkopavlovická. Scientia Horticulturae, 143, 1-6. http://dx.doi.org/10.1016/j.scienta.2012.05.022

Bátovská, A., Hrubíková, K., Bežo, M., Masnicová, S. \& Žiarovská, J. (2000) Analýza DNA polymorfizmu vybraných línií kukurice siatej (Zea mays L.) pomocou PCR-ISSR markérov. Acta fytotechnica et zootechnica.13, 15-18.

Belgorudova, I., Grauda, D., Jakobsone, G. \& Rashal, I. (2012.) Usability of retrotransposone-based molecular marker system to assess genetic diversity of Liparis loeselii. Acta Biol. Univ. Daugavp., 12, 40-43. 
Bežo, M., Ražná, K., Žiarovská, J., Štefúnová, V. \& Heldák, J. (2007). The Tst1 retrotransposon position variability in potato genotypes carrying different resistance to nematodes. Agriculture, 53, 73-80.

Buti, M., Giordani, T., Vukich, M., Gentzbittel, L., Pistelli, L., Cattonaro, M., Morgante, M., Cavallini, A. \& Natali, L. (2009). HACRE1, a recently inserted copia-like retrotransposon of sunflower (Helianthus annuи L.). Genome, 52, 904-911. http://dx.doi.org/10.1139/G09-064

Fu, D., Ma, B., Mason, A.S., Xiao, M., Wei, L. \& An, Z. (2013). MicroRNAbased molecular markers: a novel PCR-based genotyping technique in Brassica species. Plant Breeding , 132, 375-381. http://dx.doi.org/10.1111/pbr.12069

Gailīte, A., Ievinsh, G. \& Ruṇgis, D. (2011). Genetic diversity analysis of Latvian and Estonian Saussurea esthonica populations. Environmental and Experimental Biology, 9, 115-119.

Grime, J.P., Hodgson, J.G. \& Hunt, R. (1988). Comparative Plant Ecology: A Functional Approach to Common British Species. Unwin-Hyman, London, UK. Grivet, D. \& Petit, R.J. (2002). Phylogeography of the common ivy (Hedera sp.) in Europe: genetic differentiation through space and time. Molecular Ecology, 11, 1351-1362. http://dx.doi.org/10.1046/j.1365-294x.2002.01522

Guo, D.L., Guo, M.X., Hou, X.G. \& Zhang, G.H. (2014). Molecular diversity analysis of grape varieties based on iPBS markers. Biochemical Systematics and Ecology, 52, 27-32. http://dx.doi.org/10.1016/j.bse.2013.10.008

Ellenberg, H. (1988). Vegetation Ecology of Central Europe, 4th edn. Cambridge University Press, Cambridge, UK.

Hlavačková, L. \& Ražná, K. (2015). Možnost' využitia molekulových markérov na báze miRNA molekúl pre mapovanie genómu Linum usitatissimum, L. X Vedecká konferencia doktorandov FAPZ SPU v Nitre s medzinárodnou účast’ou. ISBN978-80-552-1421-4, pp. 16-19

Kalendar, R., Tanskanen, J., Immonen, S., Nevo, E. \& Schulman, A.H. (2000). Genome evolution of wild barley (Hordeum spontaneum) by BARE-1 retrotransposon dynamics in response to sharp microclimatic divergence. Proc Natl Acad Sci USA, 97, 6603-6607. http://dx.doi.org/10.1073/pnas.110587497

Kalendar, R., Tanskanen, J., Chang, W., Antonius, K., Sela, H., Peleg, O. \& Schulman, A.H. (2008). Cassandra retrotransposons carry independently transcribed 5S RNA. Proc Natl Acad Sci USA, 105, 5833-5838. http://dx.doi.org/10.1073/pnas.0709698105

Kumar, P., Gupta, V.K., Misra, A.K., Modi, D.R. \& Pandedey, B.K. (2009). Potential of molecular markers in plant biotechnology. Plant Omics Journal, 2, 41-162.

Midori, M., Clarke, S., Reichard, H.,\& Hamilton, C.W. (2006). Prevalence of different horticultural taxa of ivy (Hedera spp., Araliaceae) in invading populations. Biological Invasions , 8, 149-157. http://dx.doi.org/10.1007/s10530004-2424-6

Milella, L., Salava, J., Martelli, G. et al. (2005). Genetic Diversity between Yacon Landraces from Different Countries Based on Random Amplified Polymorphic DNAs. Czech Journal of Genetics and Plant Breeding, 41, 73-78.

Parker, K. (1996). Vegetation contribution to slope stability at Magnolia Park. Master of Science thesis, University of Washington

Reichard, S. (2000). Hedera helix. In: Randall JM and Bossard C (eds) Noxious Wildland Weeds of California, pp 212-216. University of California Press

Schäffner, K.-H. \& Nagl, W. (1979). Differential DNA replication involved in transition from juvenile to adult phase in Hedera helix (Araliaceae). Plant Systematics and Evolution, 2 (Suppl.), 105-110.

Smýkal, P., Bačová-Kertészová, N., Kalendar, R., Corander, J., Schulman, A.H. \& Pavelek, M. (2011). Genetic diversity of cultivated flax (Linum usitatissimum L.) germplasm assessed by retrotransposon-based markers. Theoretical and Applied Genetics, 122, 1385-1397. http://dx.doi.org/10.1007/s00122-011-1539-2 Sucher, N. J. \& Carles, M. C. (2008). Genome-based Approaches to the authentication of medicinal plants. Planta Med, 74, 603-623. http://dx.doi.org/10.1055/s-2008-1074517

Trebichalský, A., Kalendar, R., Schulman, A., et al. (2013). Detection of genetic relationships among spring and winter triticale $(\times$ Triticosecale witt.) and rye cultivars (Secale cereale L.) by using retrotransposon-based markers. Czech Journal of Genetics and Plant Breeding, 49, 171-174.

Vargas, P., McAllister, H.A., Morton, C., Jury, S.L. \& Wilkinson, M.J. (1999). Polyploid speciation in Hedera (Araliaceae): phylogenetic and biogeographic insights based on chromosome counts and ITS sequences. Plant Systematics and Evolution, 219, 165-179.

Vivodík, M., Balážová, Ž. \& Gálová, Z. (2014). DNA analysis of ricin using RAPD technique. Journal of Microbiology, Biotechnology and Food Sciences, 3 , 181-183.

Vivodík, M., Balážová, Ž., Gálová, Z. \& Kutka Hlozáková, T. (2015). Differentiation of ricin using RAPD markers. Pakistan Journal of Botany. 47 , s. $1341-1345$.

Žiarovská, J. \& Bežo, M.(2013). Inter HACRE-1 retrotransposon length polymorphism is not conserved throught the sunflower lines. Journal of Microbiology, Biotechnology and Food Sciences , 2, 1629-1641. 